\title{
Shewanella spongiae sp. nov., isolated from a marine sponge
}

\author{
Sung-Hyun Yang, Kae Kyoung Kwon, Hee-Soon Lee and Sang-Jin Kim
}

Correspondence

Sang-Jin Kim

s-jkim@kordi.re.kr
Marine and Extreme Genome Research Center, Korea Ocean Research and Development Institute, PO Box 29, Ansan, 425-600, Republic of Korea
A psychrophilic bacterium, designated strain $\mathrm{HJO} 9^{\top}$, was isolated from a marine sponge collected in the East Sea of Korea (also known as the Sea of Japan). Cells were Gram-negative, motile and rod-shaped (1.8-3.54 $\mu \mathrm{m} \times 0.27-0.73 \mu \mathrm{m})$. Growth was observed between 5 and $26{ }^{\circ} \mathrm{C}$ (optimum $15^{\circ} \mathrm{C}$ ), at $\mathrm{pH} 5 \cdot 0-8.5$ (optimum $\mathrm{pH} 6 \cdot 0-6 \cdot 5$ ) and in the presence of $0-6 \cdot 0 \% \mathrm{NaCl}$ (optimum $2.0 \%$ ). The $16 \mathrm{~S}$ rRNA gene sequence of strain $\mathrm{HJO}^{\top} 9^{\top}$ showed high levels of similarity (93.7-95.4\%) with members of the genus Shewanella, especially with Shewanella gaetbuli TF-27 $7^{\top}(95 \cdot 2 \%)$, Shewanella decolorationis S12 ${ }^{\top}(94 \cdot 9 \%)$, Shewanella putrefaciens LMG $26268^{\top}(94.6 \%)$, Shewanella hafniensis P010 $(94 \cdot 6 \%)$, Shewanella algae ATCC $51192^{\top}$ $(94.5 \%)$ and Shewanella kaireitica $c 931^{\top}$ (94.5\%). However, phylogenetic analysis revealed that strain $\mathrm{HJ}_{039^{\top}}$ shared a phyletic line with $S$. algae and Shewanella amazonensis. The major respiratory quinone was $\mathrm{Q}-8$. The DNA G $+\mathrm{C}$ content was $52 \cdot 8 \mathrm{~mol} \%$. The major fatty acids were i-13: 0 (8.5\%), $15: 0$ (4.2\%), i-15: 0 (23.2\%), i-15: 1 (7.9\%), $16: 0$ (8.7\%), $16: 1 \omega 7$ (21.0\%) and $17: 1 \omega 8(6 \cdot 4 \%)$. From this polyphasic taxonomic evidence, strain $\mathrm{HJO}^{\top} 9^{\top}$ is considered to represent a novel species of the genus Shewanella, for which the name Shewanella spongiae sp. nov. is proposed. The type strain is $\mathrm{HJO39}^{\top}\left(=\mathrm{KCCM} 42304^{\top}=\mathrm{JCM} 13830^{\top}\right)$.
The genus Shewanella MacDonell and Colwell 1985 comprises a group of Gram-negative, motile, rod-shaped, oxidase-positive, non-fermentative and facultatively anaerobic aquatic and marine bacteria with genomic DNA G $+\mathrm{C}$ contents of 42-55 mol\% (Bowman, 2005; Gauthier et al., 1995; MacDonell \& Colwell, 1985; Venkateswaran et al., 1999). The genus Shewanella is a member of the Gammaproteobacteria (Anzai et al., 2000) and at the time of writing comprised 34 recognized species (see http:// www.bacterio.cict.fr/s/shewanella.html and http://www. ncbi.nlm.nih.gov/Taxonomy/Browser/wwwtax.cgi). Strains belonging to members of the genus Shewanella have been isolated from a variety of sources including marine environments (Bozal et al., 2002; Ivanova et al., 2001; Nealson et al., 1991), clinical samples (Brink et al., 1995; Nozue et al., 1992; Venkateswaran et al., 1999), sediments (Myers \& Nealson, 1988; Zhao et al., 2005) and oilfield fluids (Semple \& Westlake, 1987). They have also been strongly implicated as opportunistic pathogens of humans and aquatic animals (Aguirre et al., 1994; Brink et al., 1995) and as the causal agents of proteinaceous food spoilage

The GenBank/EMBL/DDBJ accession number for the 16S rRNA gene sequence of strain $\mathrm{HJO39}^{\top}$ is DQ167234.

A table detailing the fatty acid content of strain $\mathrm{HJO39}^{\top}$ and closely related species of the genus Shewanella is available as supplementary material in IJSEM Online.
(Jorgensen \& Huß, 1989). Shewanella species have also been known to be important in the context of bioremediation, because of their considerable potential for co-metabolic bioremediation of halogenated organic pollutants (Petrovskis et al., 1994), destructive souring of crude petroleum (Semple \& Westlake, 1987), and dissimilatory reduction of manganese and iron oxides (Myers \& Nealson, 1988), uranium (Lovley \& Phillips, 1988) and other compounds (Kostka et al., 1996; Perry et al., 1993). In this study, we report the taxonomic properties of a novel psychrophilic species of Shewanella isolated from marine sponge.

Strain $\mathrm{HJ} 039^{\mathrm{T}}$ was isolated from a marine sponge living at $20 \mathrm{~m}$ water depth of the East Sea, Korea (also known as the Sea of Japan). A sponge sample was homogenized and diluted with sterilized seawater, spread onto solid marine agar 2216 (MA; Difco) and then incubated at $10{ }^{\circ} \mathrm{C}$ for 1 week. Individual colonies were isolated from MA and the morphologically distinct strain $\mathrm{HJ} 039^{\mathrm{T}}$ was selected for further characterization.

Unless otherwise stated, physiological and morphological characterization was conducted according to the methods of Sohn et al. (2004) and Kwon et al. (2005). The bacterial suspension used to inoculate the API 20E, API ZYM (bioMérieux) and Microlog GN2 (Biolog) systems was prepared in a $2 \%$ sea salt (Sigma) solution. To confirm anaerobic growth, cells were inoculated into marine broth 
2216 in a serum vial capped with an aluminium seal and cultivated at $15{ }^{\circ} \mathrm{C}$ for 2 days. The physiological, biochemical and morphological characteristics of strain $\mathrm{HJ} 039^{\mathrm{T}}$ are given in the species description and in Table 1.

The cellular fatty acid profile of strain $\mathrm{HJ} 039^{\mathrm{T}}$ was determined from 2-day-old culture at $15^{\circ} \mathrm{C}$ according to the procedure described by Sohn et al. (2004). Dominant fatty acids were i-13:0 (8.5\%), 15:0 (4.2\%), i-15:0

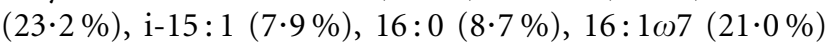
and $17: 1 \omega 8(6 \cdot 4 \%)$ (see Supplementary Table S1 in IJSEM Online). The major respiratory quinone was Q-8, as determined by HPLC analysis (according to the method of Collins, 1985). The DNA G $+\mathrm{C}$ content was $52 \cdot 8 \mathrm{~mol} \%$, as determined by HPLC using a symmetry reversed-phase C18 column (Waters) (Stackebrandt \& Liesack, 1993).

Extraction of genomic DNA and amplification of the $16 \mathrm{~S}$ rRNA gene were conducted according to Sohn et al. (2004) and a phylogenetic analysis using the 16S rRNA gene sequence was conducted according to the procedure described by Kwon et al. (2005). The 16S rRNA gene sequence of strain $\mathrm{HJ} 039^{\mathrm{T}}$ comprised a continuous stretch of $1474 \mathrm{nt}$, and approximately $1350 \mathrm{bp}$ corresponding to positions 94-1440 of the Escherichia coli numbering system (Weisburg et al., 1991) was compared in considerations of sequence quality. Exceptions to this were for Shewanella halifaxensis (1279 bp) and Shewanella sediminis (1271 bp) because only short sequences were available from the GenBank database. Aeromonas salmonicida CIP $103209^{\mathrm{T}}$ (GenBank accession no. X74681) and Ferrimonas balearica DSM $9799^{\mathrm{T}}$ (GenBank accession no. X93021) served as outgroups for phylogenetic analysis. Sequence similarity after alignment indicated that the closest relatives of strain $\mathrm{HJ} 039^{\mathrm{T}}$ were Shewanella gaetbuli $\mathrm{TF}-27^{\mathrm{T}}(95 \cdot 2 \%)$, Shewanella decolorationis $\mathrm{S}_{2} 2^{\mathrm{T}}(94 \cdot 9 \%)$, Shewanella putrefaciens LMG $26268^{\mathrm{T}}(94 \cdot 6 \%)$, Shewanella hafniensis $\mathrm{P} 010^{\mathrm{T}}$ (94.6\%), Shewanella algae ATCC $51192^{\mathrm{T}}(94 \cdot 5 \%)$ and Shewanella kaireitica c $931^{\mathrm{T}}(94 \cdot 5 \%)$.

The phylogenetic tree based on 16S rRNA gene sequences of members of the genus Shewanella has been divided into two

Table 1. Physiological characteristics differentiating strain $\mathrm{HJO}^{\top}{ }^{\top}$ and the type strains of related Shewanella species

Strains: $1, \mathrm{HJ}_{039^{\mathrm{T}}}$; 2, S. gaetbuli TF- $27^{\mathrm{T}}$; 3, S. decolorationis $\mathrm{S} 12^{\mathrm{T}}$; 4, S. algae ATCC $51192^{\mathrm{T}}$; 5, S. hafniensis $\mathrm{P} 010^{\mathrm{T}}$; 6, S. putrefaciens $\mathrm{LMG}$ $26268^{\mathrm{T}}$; 7, S. amazonensis SB2B ${ }^{\mathrm{T}}$. Data for strain $\mathrm{HJ}_{039^{\mathrm{T}}}$ are from this study; data for the other taxa are from Bowman (2005), Satomi et al. (2006), Venkateswaran et al. (1999), Yoon et al. (2004) and Xu et al. (2005). +, Positive reaction; -, negative reaction; V, variable reaction; ND, not determined. All are straight, rod-shaped organisms, oxidase- and catalase-positive, and do not utilize citrate.

\begin{tabular}{|c|c|c|c|c|c|c|c|}
\hline Characteristic & 1 & 2 & 3 & 4 & 5 & 6 & 7 \\
\hline Optimal growth temperature $\left({ }^{\circ} \mathrm{C}\right)$ & 15 & 30 & $20-30$ & $25-35$ & 25 & $25-35$ & $25-35$ \\
\hline Optimal $\mathrm{pH}$ for growth & $6-6 \cdot 5$ & $7-8$ & 8 & $7-8$ & ND & $7-8$ & $7-8$ \\
\hline $4{ }^{\circ} \mathrm{C}$ after $24 \mathrm{~h}$ & + & - & + & - & + & + & + \\
\hline $35^{\circ} \mathrm{C}$ & - & + & + & + & - & $\mathrm{V}$ & + \\
\hline $\mathrm{NO}_{3}$ to $\mathrm{NO}_{2}$ & - & - & + & + & + & + & + \\
\hline $\mathrm{NO}_{2}$ to $\mathrm{N}_{2}$ & - & - & + & - & ND & - & + \\
\hline Haemolysis & $\mathrm{ND}$ & + & $\mathrm{ND}$ & $\mathrm{v}$ & ND & - & + \\
\hline \multicolumn{8}{|l|}{ Growth in the presence of: } \\
\hline $0 \% \mathrm{NaCl}$ & + & - & + & + & + & + & + \\
\hline Amylase & - & + & - & - & ND & - & - \\
\hline Gelatinase & + & + & + & $\mathrm{V}$ & + & - & + \\
\hline Lipase & - & + & ND & - & ND & - & - \\
\hline \multicolumn{8}{|l|}{ Utilization of: } \\
\hline D-Galactose & - & - & - & $\mathrm{V}$ & ND & + & + \\
\hline D-Fructose & + & - & V & - & ND & - & - \\
\hline Sucrose & + & - & + & - & - & $\mathrm{V}$ & - \\
\hline Succinate & - & - & + & $\mathrm{V}$ & ND & $\mathrm{V}$ & + \\
\hline DL-Lactate & - & - & + & + & + & $\mathrm{V}$ & + \\
\hline DNA G $+\mathrm{C}$ content $(\mathrm{mol} \%)$ & $52 \cdot 8$ & 42 & $49 \cdot 3$ & $52-55$ & 47 & $43-47$ & 52 \\
\hline
\end{tabular}


major groups, with S. algae and Shewanella amazonensis forming relatively distinct branches (Bowman, 2005). The first group (group I) includes psychrotolerant, nonhalophilic strains and the second group (group II) includes psychrotolerant, $\mathrm{Na}^{+}$-requiring strains. According to this definition, the six closest relatives of strain $\mathrm{HJ} 039^{\mathrm{T}}$ could be affiliated into group II with the exception of S. kaireitica. However, strain $\mathrm{HJ} 039^{\mathrm{T}}$ shared a phyletic line with $S$. algae and $S$. amazonensis rather than with $S$. gaetbuli, $S$. decolorationis, etc., within group II (Fig. 1). This result matched well with the DNA G $+\mathrm{C}$ values $(>50 \mathrm{~mol} \%$ for strain $\mathrm{HJ} 039^{\mathrm{T}}$, S. algae and S. amazonensis), although these data cannot be used to specify the phylogenetic position of any particular strain.

Strain $\mathrm{HJ} 039^{\mathrm{T}}$ did not have an obligate $\mathrm{Na}^{+}$requirement for growth, although the presence of $\mathrm{Na}^{+}$ions enhanced growth, a trait observed for other members of Shewanella group II. Some characteristics, such as utilization of Dfructose and sucrose, lack of nitrate-reducing ability and high levels of the fatty acid i-15:1, can be used to differentiate strain $\mathrm{HJ} 039^{\mathrm{T}}$ from closely related members of the genus Shewanella. On the basis of this polyphasic taxonomic evidence, strain $\mathrm{HJ} 039^{\mathrm{T}}$ is considered to represent a novel species of the genus Shewanella, for which the name Shewanella spongiae sp. nov. is proposed.

\section{Description of Shewanella spongiae sp. nov.}

Shewanella spongiae (spon.gi'ae. L. gen. n. spongiae of a sponge, the source of the type strain).

Cells are Gram-negative, rod-shaped $(1 \cdot 8-3 \cdot 54 \mu \mathrm{m} \times 0 \cdot 27-$ $0.73 \mu \mathrm{m})$ and motile. Cells appear singly or in chains. Colonies formed after 2 days on MA at $15^{\circ} \mathrm{C}$ are white, circular, opaque and convex with entire margins. Growth does not occur under anaerobic conditions on MA. Growth is observed at $5-26{ }^{\circ} \mathrm{C}$ (optimum $15^{\circ} \mathrm{C}$ ), $\mathrm{pH} 5 \cdot 0-8 \cdot 5$ (optimum 6.0-6.5) and in the presence of $0-6 \%(\mathrm{w} / \mathrm{v})$ $\mathrm{NaCl}$ (optimum $2 \cdot 0 \%$ ). Produces oxidase and catalase. When assayed with the API ZYM system, esterase (C4), esterase lipase (C8), alkaline phosphatase, leucine arylamidase, acid phosphatase and naphthol-AS-BI-phosphohydrolase are present and valine arylamidase activity is weakly positive. Negative for lipase (C14), cystine arylamidase, trypsin, $\alpha$-chymotrypsin, $\alpha$-galactosidase, $\beta$-galactosi-

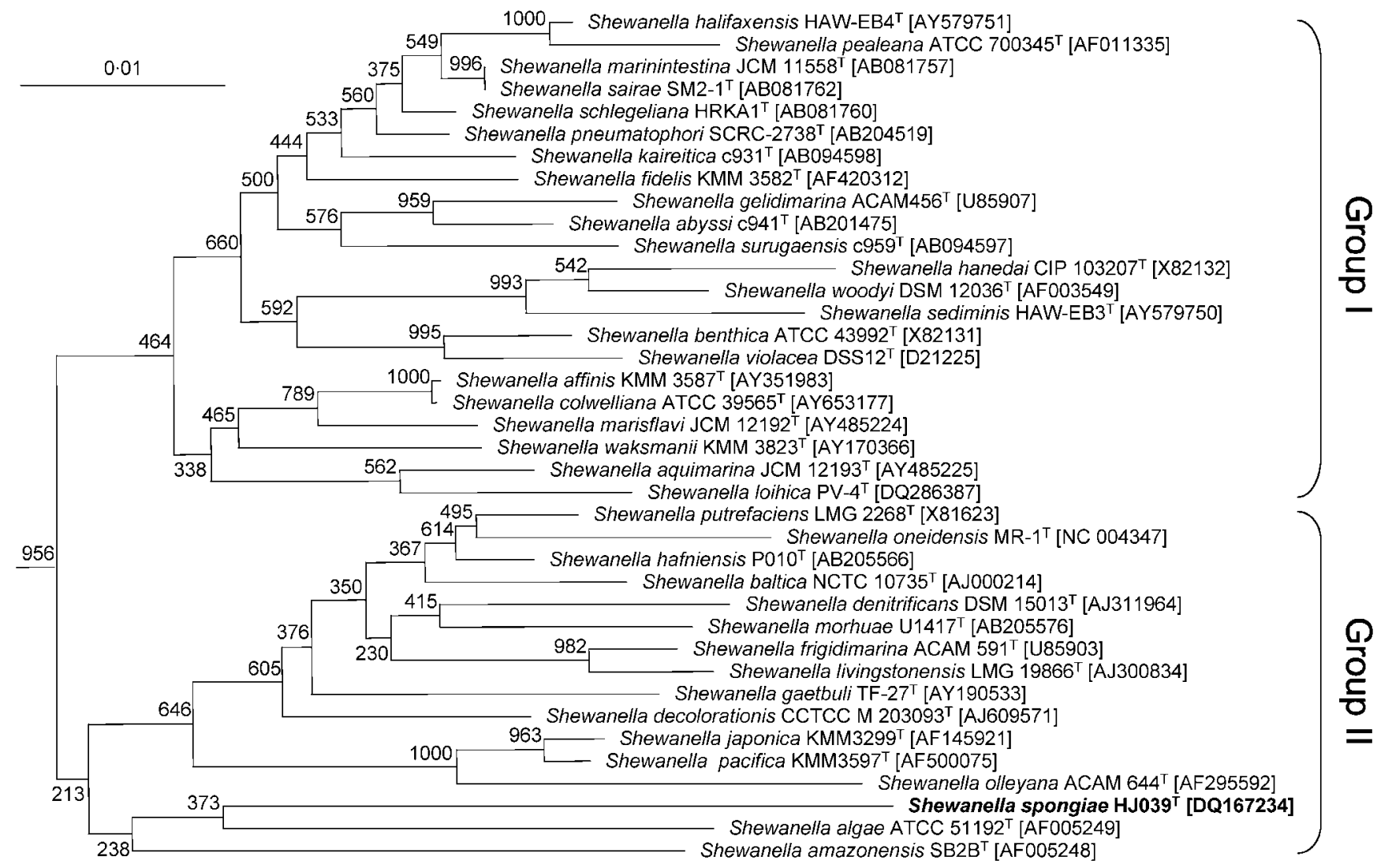

Fig. 1. Rooted neighbour-joining tree based on nearly complete $16 \mathrm{~S}$ rRNA gene sequences showing the relationship between strain $\mathrm{HJO} 9^{\top}$ and members of the genus Shewanella. Approximately 1350 bp corresponding to positions $94-1440$ of the E. coli numbering system was compared. Bootstrap values of 1000 resampled datasets at all nodes are shown. Bar, 0.01 substitutions per nucleotide position. 
dase, $\beta$-glucuronidase, $\alpha$-glucosidase, $\beta$-glucosidase, $N$-acetyl- $\beta$-glucosaminidase, $\alpha$-mannosidase and $\alpha$-fucosidase. Degrades sucrose, D-trehalose, dextrin, D-arabitol, Dfructose, $\alpha$-D-glucose, D-mannose and L-serine and can utilize turanose (weakly) on Microlog GN2 plates. Major

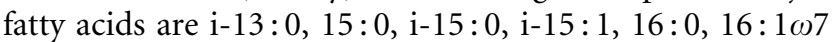
and $17: 1 \omega 8$. The major respiratory quinone is $\mathrm{Q}-8$. The DNA G $+\mathrm{C}$ content is $52 \cdot 8 \mathrm{~mol} \%$.

The type strain, HJ039 $9^{\mathrm{T}}\left(=\mathrm{KCCM} 42304^{\mathrm{T}}=\mathrm{JCM} 13830^{\mathrm{T}}\right)$, was isolated from a marine sponge in the East Sea, Korea, at $20 \mathrm{~m}$ water depth.

\section{Acknowledgements}

This work was supported by the Marine and Extreme Genome Research Center Program of the Ministry of Marine Affairs and Fisheries, Korea. Special thanks are due to Dr J. P. Euzéby for nomenclature and Y. Y. Yoon (Kwandong University) for provision of SCUBA-diving and laboratory facilities.

\section{References}

Aguirre, A. A., Balazas, G. H., Zimmerman, B. \& Spraker, T. R. (1994). Evaluation of Hawaiian green turtles (Cheledonia mydas) for potential pathogens associated with fibropapillomas. J Wild Dis 30, 8-15.

Anzai, Y., Kim, H., Park, J. Y., Wakabayashi, H. \& Oyaizu, H. (2000). Phylogenetic affiliation of the pseudomonads based on 16S rRNA sequence. Int J Syst Evol Microbiol 50, 1563-1589.

Bowman, J. P. (2005). Genus XIII. Shewanella MacDonell and Colwell 1986, 355 ${ }^{\mathrm{VP}}$ (Effective publication: MacDonell and Colwell 1985, 180). In Bergey's Manual of Systematic Bacteriology, 2nd edn, vol. 2, part B, pp. 480-491. Edited by D. J. Brenner, N. R. Crieg, J. T. Staley \& G. M. Garrity. New York: Springer.

Bozal, N., Montes, M. J., Tudela, E., Jiménez, F. \& Guinea, J. (2002). Shewanella frigidimarina and Shewanella livingstonensis sp. nov. isolated from Antarctic coastal areas. Int J Syst Evol Microbiol 52, 195-205.

Brink, A. J., van Straten, A. \& van Rensburg, A. J. (1995). Shewanella (Pseudomonas) putrefaciens bacteremia. Clin Infect Dis 20, 1327-1332.

Collins, M. D. (1985). Isoprenoid quinone analysis in bacterial classification and identification. In Chemical Methods in Bacterial Systematics, pp. 267-287. Edited by M. Goodfellow \& D. E. Minnikin. London: Academic Press.

Gauthier, G., Gauthier, M. \& Christen, R. (1995). Phylogenetic analysis of the genera Alteromonas, Shewanella, and Moritella using genes coding for small-subunit rRNA sequences and division of the genus Alteromonas into two genera, Alteromonas (emended) and Pseudoalteromonas gen. nov., and proposal of twelve new species combinations. Int J Syst Bacteriol 45, 755-761.

Ivanova, E. P., Sawabe, T., Gorshkova, N. M., Svetashev, V. I., Mikhailov, V. V., Nicolau, D. V. \& Christen, R. (2001). Shewanella japonica sp. nov. Int J Syst Evol Microbiol 51, 1027-1033.

Jorgensen, B. R. \& Huß, H. H. (1989). Growth and activity of Shewanella putrefaciens isolated from spoiling fish. Int J Food Microbiol 9, 51-62.

Kostka, J. E., Stucki, J. W., Nealson, K. H. \& Wu, J. (1996). Reduction of structural $\mathrm{Fe}(\mathrm{III})$ in smectite by a pure culture of Shewanella putrefaciens strain MR-1. Clays Clay Miner 44, 522-529.
Kwon, K. K., Lee, H.-S., Yang, S. H. \& Kim, S.-J. (2005). Kordiimonas gwangyangensis gen. nov., sp. nov., a marine bacterium isolated from marine sediments that forms a distinct phyletic lineage (Kordiimonadales ord. nov.) in the 'Alphaproteobacteria'. Int J Syst Evol Microbiol 55, 2033-2037.

Lovley, D. R. \& Phillips, E. J. P. (1988). Novel mode of microbial energy metabolism: organic carbon oxidation coupled to dissimilatory reduction of iron or manganese. Appl Environ Microbiol 54, 1472-1480.

MacDonell, M. T. \& Colwell, R. R. (1985). Phylogeny of the Vibrionaceae, and recommendation for two new genera, Listonella and Shewanella. Syst Appl Microbiol 6, 171-182.

Myers, C. R. \& Nealson, K. H. (1988). Manganese reduction bacteria and growth with manganese oxide as the sole electron acceptor. Science 240, 1319-1321.

Nealson, K. H., Myers, C. R. \& Wimpee, B. (1991). Isolation and identification of manganese reducing bacteria, and estimates of microbial manganese reducing potential in the Black Sea. Deep Sea Res 38, S907-S920.

Nozue, H., Hayashi, T., Hashimoto, Y., Ezaki, T., Hamasaki, K., Ohwada, K. \& Terawaki, Y. (1992). Isolation and characterization of Shewanella algae from human clinical specimens and emendation of the description of S. algae Simidu et al., 1990, 335. Int J Syst Bacteriol 42, 628-634.

Perry, K. A., Kostka, J. E., Luther, G. W., III \& Nealson, K. H. (1993). Mediation of sulfur speciation by a Black Sea facultative anaerobe. Science 259, 801-803.

Petrovskis, E. A., Vogel, T. M. \& Adriaens, P. (1994). Effects of electron acceptors and donors on transformation of tetrachloromethane by Shewanella putrefaciens MR-1. FEMS Microbiol Lett 121, 357-364.

Satomi, M., Vogel, B. F., Gram, L. \& Venkateswaran, K. (2006). Shewanella hafniensis sp. nov. and Shewanella morhuae sp. nov., isolated from marine fish of the Baltic Sea. Int J Syst Evol Microbiol 56, 243-249.

Semple, K. M. \& Westlake, D. W. S. (1987). Characterization of iron reducing Alteromonas putrefaciens strains from oil field fluids. Can J Microbiol 35, 925-931.

Sohn, J. H., Kwon, K. K., Kang, J.-H., Jung, H.-B. \& Kim, S.-J. (2004). Novosphingobium pentaromativorans sp. nov., a high-molecular-mass polycyclic aromatic hydrocarbon-degrading bacterium isolated from estuarine sediment. Int J Syst Evol Microbiol 54, 1483-1487.

Stackebrandt, E. \& Liesack, W. (1993). Nucleic acids and classification. In Handbook of New Bacterial Systematics, pp. 158-160. Edited by M. Goodfellow \& A. G. O’Donnell. London: Academic Press.

Venkateswaran, K., Moser, D. P., Dollhopf, M. E. \& 10 other authors (1999). Polyphasic taxonomy of the genus Shewanella and description of Shewanella oneidensis sp. nov. Int J Syst Bacteriol 49, 705-724.

Weisburg, W. G., Barns, S. M., Pelletier, D. A. \& Lane, D. J. (1991). $16 \mathrm{~S}$ ribosomal DNA amplification for phylogenetic study. J Bacteriol 173, 697-703.

Xu, M., Guo, J., Cen, Y., Zhong, X., Cao, W. \& Sun, G. (2005). Shewanella decolorationis sp. nov., a dye-decolorizing bacterium isolated from activated sludge of a waste-water treatment plant. Int J Syst Evol Microbiol 55, 363-368.

Yoon, J.-H., Kang, K. H., Oh, T.-K. \& Park, Y.-H. (2004). Shewanella gaetbuli sp. nov., a slight halophile isolated from a tidal flat in Korea. Int J Syst Evol Microbiol 54, 487-491.

Zhao, J.-S., Manno, D., Beaulieu, C., Paquet, L. \& Hawari, J. (2005). Shewanella sediminis sp. nov., a novel $\mathrm{Na}^{+}$-requiring and hexahydro-1,3,5-trinitro-1,3,5-triazine-degrading bacterium from marine sediment. Int J Syst Evol Microbiol 55, 1511-1520. 